\title{
MIGRASI DAN INTERAKSI ANTARETNIS DI KABUPATEN PASAMAN BARAT PROVINSI SUMATERA BARAT
}

\author{
ETHNIC MIGRATION AND INTERACTION \\ IN PASAMAN BARAT DISTRICT, WEST SUMATERA PROVINCE
}

\author{
Undri \\ Balai Pelestarian Nilai Budaya Sumatera Barat \\ Jl. Raya Belimbing No. 16 A, Kuranji, Padang \\ e-mail: undri_siun@yahoo.com
}

Naskah diterima 23 Oktober 2018, diterima setelah perbaikan 26 November 2018, disetujui untuk dicetak 28 November 2018

\begin{abstract}
Abstrak
Tulisan ini menjelaskan tentang migrasi dan interaksi antaretnis yakni Minangkabau, Mandailing, dan Jawa di daerah Pasaman Barat Provinsi Sumatera Barat. Interaksi ketiga etnis tersebut tidak terlepas dari proses migrasi. Di rantaunya Minangkabau tersebut etnik Minangkabau sebagai penduduk asli (urang asa) menganggap dua etnis yakni Mandailing dan Jawa sebagai penduduk pendatang (urang datang). Penelitian ini mengunakan metode penelitian sejarah. Dalam metode penelitian sejarah ada empat tahapan penting yakni pertama heuristic, mencari dan menemukan sumber-sumber sejarah atau pengumpulan sumber, Kedua, kritik menilai otentik atau tidaknya suatu sumber dan seberapa jauh kredibilitas sumber. Ketiga, sintesis dari fakta yang diperoleh melalui kritik sumber atau disebut juga kredibilitas sumber, dan keempat, penyajian hasilnya dalam bentuk tertulis. Hasil penelitian yakni di daerah Pasaman Barat telah terjadi interaksi ketiga etnis tersebut. Interaksi tidak terlepas dari proses migrasi. Dari proses migrasi dan interaksi telah terjadi perkawinan campuran. Salah satu daerah yang paling menarik yakni Nagari Jambak. Sebuah daerah yang berada di Pasaman Barat dan ditempati oleh tiga etnis tersebut. Perkawinan campuran antar etnis telah terjadi di daerah tersebut, perkawinan campuran yang berbeda tentu membawa perubahan dari masing-masing etnik terutama menyangkut keyakinan dan nilai budaya yang dianut oleh masyarakat dan juga memperluas jaringan kekerabatan. Perkawinan campuran dalam masyarakat yang multienik membentuk keyakinan penduduk bahwa tidak ada lagi perbedaan antar etnik, berguna untuk menghilangkan streotype etnik yang tidak baik terhadap etnik lainnya.
\end{abstract}

Kata Kunci : Migrasi, interaksi, etnik, dan Pasaman Barat.

\begin{abstract}
This paper describes the migration and interaction among ethnic groups, namely Minangkabau, Mandailing, and Java in the West Pasaman region of West Sumatra Province. The interaction omong the three ethnic groups cannot be separated from the migration process. In Minangkabau migrants, Minangkabau ethnic groups as indigenous people (urang asa) consider the two ethnic groups, Mandailing and Javanese as migrants. There are four stages in this method. The first step is heuristic, seeking, and finding historical sources. Second, criticism assesses the
\end{abstract}


authenticity of a source and the extent of source credibility. Third, synthesis of facts obtained through source criticism or also called source credibility, and fourth, presentation of results in written form. The results of the study, namely in the West Pasaman area, there have been interactions between the three ethnic groups. From the process of migration and interaction there has been a mixed marriage. One of the most interesting areas is Jambak. An area in West Pasaman and occupied by the three ethnic groups. Inter-ethnic mixed marriages have taken place in the area, different mixed marriages certainly bring changes from each ethnicity, especially regarding the beliefs and cultural values adopted by the community and also expand the network of kinship. The occurrence of mixed marriages in a multi-ethnic society, makes the population's belief that there are no more ethnic differences, useful for eliminating ethnic stereotypes.

Keywords: Migration, interaction, ethnicity, and West Pasaman.

\section{PENDAHULUAN}

Di Kabupaten Pasaman Barat sebagai daerah rantau Minangkabau, etnis Minangkabau sebagai penduduk asli (urang asa) menganggap dua etnik yakni Mandailing dan Jawa sebagai penduduk pendatang (urang datang). Sebuah cerita rakyat yang berkembang dalam masyarakat Pasaman yakni Cerita Rajo Sontang, diceritakan bahwa orang pertama yang mendiami daerah tersebut berasal dari Pagaruyung, beretnik Minangkabau. ${ }^{1}$ Kemudian, ketika maraknya perdagangan emas di Sumatera Barat kira-kira abad ke-14, orang luhak Agam, sebagian besar penduduknya menjadikan Pasaman sebagai tujuan rantau mereka.

Hal ini terjadi ketika padatnya penduduk di daerah luhak sedangkan tanah yang akan diusahakan tidak mencukupi. Penduduk luhak Agam menuju daerah-daerah yang terletak bagian utara Agam seperti Kumpulan, Bonjol, Ophir, Rao, Lubuk Sikaping, Air Bangis dan Sasak. Semua daerah ini merupakan daerah koloni penduduk luhak, dan merupakan cikal bakal sebagian besar penduduk Pasaman (Naim dalam Koentjaraningrat, 1984:64 ; Zed, 1993:24).

Setelah etnik Minangkabau menempati daerah ini, datanglah orang dari Tapanuli Selatan, yang beretnik Mandailing. Awal kedatangan mereka tidak terlepas dari munculnya gerakan Paderi, memasuki abad ke 19 di Minangkabau (Aboe Naim, 1988;53 ; Undri, 2005 ;106). Berbeda dengan migrasi orang Minangkabau dan Mandailing, migrasi orang Jawa ke Pasaman, tidak terlepas dari kedatangan pemilik modal ke daerah Pasaman awal tahun 1900-an. Walaupun sebelumnya keberadaan orang Jawa di Sumatera Barat telah ada, yakni dibawa oleh Belanda sebagai kuli kontrak dan kuli paksa untuk bekerja di tambang (de Graff dan Stibbe dalam Kahin, 2005;40).

Etnik Minangkabau, Mandailing dan Jawa mempunyai pola budaya dan sifat khas yang mengarah pada kebudayaan yang mereka miliki. Bagi penduduk pendatang (urang datang) setibanya mereka ditempat pemukiman yang baru mereka menemukan kehidupan yang baru pula, berbaur antaretnik tersebut, sudah tentu berbeda dengan daerah asal mereka dahulu bahkan semula tidak mengenal antara satu individu, kelompok dan juga etnik yang dipunyai. Masing-masing mereka mengalami perubahan-perubahan karena harus beradapatasi pada lingkungan yang baru, baik cara hidup, cara

${ }^{1}$ Tentang isi cerita ini lebih lanjut lihat Departemen Pendidikan dan Kebudayaan Tim Cerita Rakyat Sumatera Barat, 1979/1980: 180 
bergaul dan hubungan sosial lainnya. Dalam rangka hubungan antar individu khususnya dan hubungan antar etnik umumnya maka proses interaksi antar etnik dapat dilihat keberadaannya. Pertemuan latar belakang budaya yang berbeda dalam satu komunitas, hal ini mengandung makna hadirnya corak kehidupan baru yang juga ditandai oleh kebiasaan, pola tingkah laku dan nilai sosial budaya yang berbeda.

Fenomena yang sangat menarik sekarang ini, keberadaan ketiga etnik telah mendiami daerah tersebut. Ketiga etnik tersebut saling berinteraksi, baik yang berprofesi sebagai pedagang, buruh, pegawai dan lainnya. Ada beberapa wadah dalam berinteraksi seperti pasar. Fungsi pasar di samping sebagai tempat terjadinya transaksi antara penjual dan pembeli juga berfungsi sebagai tempat berlangsungnya pertemuan antar etnik, kenalan yang sudah lama tidak bertemu, menambah pergaulan, tempat mendapatkan nafkah dan lain sebagainya. Di pasar terdapat bermacam-macam orang, baik dari lapisan bawah sampai lapisan yang paling tinggi kedudukannya dalam masyarakat, petani, saudagar, nelayan, pegawai negeri, pengusaha dan lain sebagainya. Mereka berbaur dalam suasana hiruk pikuk, tawar menawar, promosi dan lain-lain.

Perkawinan campuran juga telah terjadi antar etnis yang berbeda. Hal ini menyebabkan telah membawa perubahan dari masing-masing etnik terutama menyangkut keyakinan dan nilai budaya yang dianut oleh masyarakat dan juga memperluas jaringan kekerabatan. Dapat dikatakan perkawinan campuran adalah bahagian dari terjadinya integrasi.

Media pertama dalam proses sosialisasi perkawinan antaretnis yang terjadi di daerah ini adalah ruang publik dan sebagai media dalam berinteraksi antaretnik. Hal ini tidak terlepas bahwa sebagai makhluk sosial, manusia mempunyai kepentingan untuk mengadakan komunikasi. Dengan kata lain komunikasi merupakan salah satu kebutuhan hidup bagi manusia sebagai makhluk sosial. Melalui komunikasi tersebut manusia dapat menyampaikan informasi. Berbagai pengetahuan, perasaan, dan kemauan dapat disampaikan dari satu orang ke orang lain. Kemudian dapat juga dijadikan sarana untuk mengadakan dialog yang pada akhirnya berbagai komponen dapat diambil. Sebagai suatu kelompok sosial, masyarakat senantiasa membutuhkan berbagai sarana untuk dapat mengembangkan dan menjalankan berbagai kepentingan hidupnya. Sarana tersebut berbentuk ruang publik, seperti pasar, lapangan sepak bola, posyandu, kantor pemerintah dan lain sebagainya.

Isu hubungan antar etnis itu sendiri merupakan isu yang sudah cukup lazim dan cukup sering dikaji. Namun selama proses sosial masih berlangsung dalam sebuah masyarakat, maka kajian ini tidak akan pernah berhenti. Irwan Abdullah (2006 :80) menggambarkan bagaimana konflik-konflik yang terjadi di berbagai daerah di Indonesia. Konflik etnis yang terjadi di berbagai tempat itu menegaskan bahwa etnis tidaklah hadir dalam suatu ruang kosong, tetapi hadir dalam suatu parameter sosial. Konflik etnis tersebut, juga ada yang berujung kepada konflik antar agama. Berbagai kasus di Indonesia dalam parahon 1990-an di Situbondo, Maluku, Kupang, Poso, Sambas, dan lain-lain tidak terlepas dari "muatan" agama di atas isu-isu kesenjangan ekonomi dan sosial. Pada sisi lain, agama pun memiliki kekuatan perekat lintas etnik, strata sosial, geografis, dan peran sosial yang kuat dari berbagai lapisan warga masyarakat.

Namun, akhir-akhir ini, kebanggaan bangsa Indonesia tentang keragaman suku bangsa sedikit terusik disebabkan berbagai konflik yang melibakan antar suku bangsa. Berbagai kasus konflik seperti: di Ambon (Maluku), Pontianak (Kalimantan Barat), Sampit-Mataram (NTB) dan Poso (Sulawesi Tengah), dan daerah lainnya adalah merupakan berbagai contoh kasus konflik yang disebabkan oleh 
pertikaian antar etnis komunitas agama, dan/atau antar golongan yang terjadi di berbagai kawasan di Indonesia. Bahkan persatuan dan kesatuan bangsa terancam goyah akibat konflik atnik tersebut. Berbagai kalangan mengemukakan penyebab terjadinya konflik antara lain karena kesenjangan ekonomi, perbedaan agama, permusuhan dan dendam antar suku dan permainan propokator.

Bertitik total dari persoalan diatas, tulisan ini memfokuskan tentang migrasi dan interaksi antar etnik yakni Minangkabau, Mandailing, dan Jawa di daerah Pasaman Barat Provinsi Sumatera Barat. Di daerah rantau Minangkabau tersebut, etnik Minangkabau sebagai penduduk asli (urang asa) menganggap dua etnik yakni Mandailing dan Jawa sebagai penduduk pendatang (urang datang).

Rangkaian pertanyaan berikut ini dapat membantu mengarahkan pokok-pokok persoalan secara lebih jelas. Adapun pertanyaan yang akan dirumuskan dalam penelitian ini adalah sebagai berikut : (1) bagaimana proses migrasi etnik ke Kabupaten Pasaman Barat Provinsi Sumatera Barat ?, (2) bagaimana interaksi antar etnik di Kabupaten Pasaman Barat Provinsi Sumatera Barat ?, (3) faktor-faktor apa saja yang mendorong dan menghambat terjalinnya interaksi antar etnik di Kabupaten Pasaman Barat Provinsi Sumatera Barat ? (4) bagaimana pengaruh migrasi dan interaksi antar etnik bagi kehidupan sosial-ekonomi masyarakat di Kabupaten Pasaman Barat Provinsi Sumatera Barat?

Adapun batasan spasial dalam pembahasan ini adalah Kabupaten Pasaman Barat Provinsi Sumatera Barat. Daerah tersebut sampai sekarang ini dihuni oleh etnik mayoritas yakni etnik Minangkabau, Jawa dan Mandailing. Kehadiran etnik tersebut masih eksis sampai sekarang, mereka bukan lagi menjadi orang Minangkabau, Jawa, dan Mandailing tapi telah menjadi orang Pasaman sendiri. Sebuah proses akulturasi yang berakar dari masa lalu.

Batasan temporal dalam pembahasan ini adalah dari tahun 1930 sampai 2018. Tahun 1930 diambil sebagai batasan awalnya karena pada tahun tersebut etnik Mandailing bermigrasi ke daerah tersebut secara besar-besaran. Tercatat dari 37.612 orang yang bermigrasi keseluruh Indonesia sebanyak 25.945 orang (68.9\%) bermigrasi ke daerah Sumatera Barat khususnya ke Pasaman. ${ }^{2}$ Kampung halaman orang Mandailing bersebelahan, tepatnya sebelah utara Pasaman, sehingga telah memungkinkan mereka untuk bermigrasi ke daerah tetangganya tersebut.

Tahun 2018 diambil sebagai batasan akhirnya, karena proses sosial masih berlangsung sampai sekarang. Menurut Irwan Abdullah (2006), sebab proses sosial masih berlangsung dalam sebuah masyarakat, maka kajian ini tidak akan pernah berhenti dikaji, baik dari segi substansi isi maupun waktu.

Sebagai suatu kajian historis, secara akademik penelitian ini kiranya bermanfaat sebagai informasi awal bagi usaha penelitian lebih lanjut tentang berbagai persoalan etnik. Dengan kata lain, penelitian ini memberikan sumbangan bagi salah-satu aspek sosial budaya dari penulisan sejarah lokal Kabupaten Pasaman Barat Provinsi Sumatera Barat, sampai sekarang ini belum banyak diketahui dan dikaji. ${ }^{3}$

Secara umum penelitian ini bertujuan untuk menghasilkan rekonstruksi yang komprehensif tentang migrasi dan interaksi antar etnik serta melihat pola sebuah migrasi dan interaksi antar etnik.

${ }^{2}$ Angka tersebut berdasarkan Volkstelling 1930, IV, hal. 162-163 : VII, hal. 94. Secara terperinci migrasi mereka keberbagai daerah di Indonesia adalah sebagai berikut : Aceh 7.368 orang, Sumatera Barat $=25.945$ orang, bagianbagian lain Sumatera $=1.352$ orang, Jawa dan Madura $=2.453$ orang, bagian-bagian lain di Indonesia $=443$ orang dan Semenanjung Malaya = 51 orang. Secara keseluruhan adalah 37.612 orang. Lebih jelas lihat Koentjaraningrat (Penyunting), 1984, hal.285. 
Secara terapan, penelitian ini juga berpretensi untuk mengembangkan wawasan pengetahuan mengenai salah-satu varian dari kehidupan sosial budaya, serta memahami lebih jauh tentang persoalan migrasi dan interaksi antar etnik di Kabupaten Pasaman Barat Provinsi Sumatera Barat. Pada gilirannya, penelitian ini kiranya memberikan manfaat bagi penentu kebijakan untuk mengelola dan memberdayakan kehidupan sosial budaya masyarakat yang ada di Kabupaten Pasaman Barat Provinsi Sumatera Barat.

\section{METODE PENELITIAN}

Penelitian ini mengunakan metode penelitian sejarah. Metode penelitian sejarah akan melalui empat tahapan penting yakni pertama heuristic mencari dan menemukan sumber-sumber sejarah atau pengumpulan sumber. Kedua, kritik menilai otentik atau tidaknya sesuatu sumber dan seberapa jauh kredibilitas sumber. Ketiga, sistesis dari fakta yang diperoleh melalui kritik sumber atau disebut juga kredibilitas sumber, dan keempat, penyajian hasilnya dalam bentuk tertulis (Gottschalk, 1985 : 32 ; Kuntowijoyo, 1999 : 89).

Pengumpulan sumber dilakukan melalui studi kepustakaan dan studi lapangan. Studi kepustakaan di Arsip Nasional Republik Indonesia (ANRI) di Jakarta, Perpustakaan Nasional Republik Indonesia di Jakarta, Perpustakaan Fakultas Ilmu Budaya Universitas Andalas di Padang, Perpustakaan Pusat Dokumentasi dan Informasi Kebudayaan Minangkabau di Padang Panjang, Biro Pusat Statistik Propinsi Sumatera Barat di Padang, Biro Pusat Statistik Kabupaten Pasaman Barat di Simpang Empat, dan lainnya.

Untuk menutupi kekurangan dan keterbatasan sumber dan bahan tertulis tentang keadaan masyarakat digunakan sumber wawancara. Wawancara dilakukan terhadap sejumlah penduduk, baik penduduk asli maupun penduduk pendatang yang sezaman dengannya. Informan kunci (key informant) seperti tokoh adat dari etnis Minangkabau, Mandailing, dan Jawa. Wawancara juga dilakukan terhadap pihak pemerintah seperti walinagari, camat, dan sebagainya. Hasil wawancara tersebut dilakukan pengujian data dengan wawancara silang guna mendapatkan data yang orisinil.

Tahap kedua, kritik yaitu tahap penyeleksian sumber-sumber sejarah. Meliputi kritik eksteren dan intern. Kritik ekstern ini dilakukan untuk menguji tingkat keabsahan sumber (otentisitas sumber) sedangkan kritik intern dilakukan untuk menguji tingkat kepercayaan sumber (kredibilitas sumber). Tahapan ini, melakukan kritik terhadap pendapat yang berbeda baik melalui tulisan sejarawan ataupun sumber lisan berupa wawancara antara pencerita yang satu dengan yang lainnya.

Tahap ketiga dalam hal ini adalah interpretasi dalam arti merangkaikan fakta-fakta lainnya menjadi suatu kesatuan pengertian. Pada akhirnya fakta sejarah yang telah mempunyai makna tersebut dituliskan secara integral dalam suatu cerita sejarah. Tentu saja fakta sejarah yang sesuai dan ada relevannya dengan topik yang dibahas.

Beberapa bahan arsip yang dimanfaatkan dalam penelitian ini, terutama berupa (1) Salinan Surat Penjerahan Tanah dari Walinagari Kepada Pemerintah Republik Indonesia. Tertanggal 18 Mei 1953. Surat tersebut berisi tentang penyerahan tanah oleh walinagari di Pasaman Barat kepada

\footnotetext{
${ }^{3}$ Menurut Taufik Abdullah, sejarah lokal adalah sebagai kisah dikelampauan dari kelompok atau kelompokkelompok masyarakat yang berada pada " daerah geografis" yang terbatas. Mengenai perihal sejarah lokal lebih lanjut lihat Abdullah, 1996: 15.
} 
pemerintah daerah untuk transmigrasi, dan (2) Surat Keterangan Bupati/Kepala Daerah Kabupaten Pasaman, Lubuk Sikaping. Tertanggal 25 April 1953. Surat tentang tidak keberatannya pemerintah daerah Kabupaten Pasaman atas kedatangan para transmigrasi Jawa ke daerahnya.

Sumber yang amat terpenting yang terbit sezaman yang dimanfaatkan untuk penelitian ini adalah berita koran Haluan, Soerat Chabar Peroesahaan Tanah, Majalah Tani dan Majalah Pegawai Boemi Poetra terbitan Padang. Sumber-sumber tertulis tersebut sekarang ada di Perpustakaan Nasional di Jakarta, Arsip Nasional Republik Indonesia di Jakarta, dan Pusat Dokumentasi dan Informasi Kebudayaan Minangkabau (PDIKM) di Padangpanjang Propinsi Sumatera Barat.

Disamping itu ada beberapa hasil penelitian terdahulu yang mengulas terutama tentang Sumatera Barat umumnya dan daerah penelitian khususnya. Sumber-sumber tersebut antara lain adalah : (1) Elizabeth Graves, The Minangkabau response to Dutch Colonial rule in the nineteenth century (Monograph series). Ithaca, New York : Cornell University, 1981, (2) Akira Oki,"Social change in the West Sumatran Village. 1908-1945" Thesis Doctor. Canberra : The Australian University, 1977, (3) Christine Dobbin, Kebangkitan Islam dalam ekonomi petani yang sedang berubah, Sumatera Tengah, 1784-1847. Jakarta : INIS,1992, (4) Westenenk.L.C. Nagari Minangkabau. Terjemahan oleh Mahyuddin Saleh. Padang : Bursa Fakultas Hukum Universitas Andalas [1978], (5) S.M.Hardjo, Bunga rampai dari Suriname ke Tongar. Jakarta: Balai Pustaka, 1989. Sebuah memoir yang berisi tentang pengalaman yang pernah dilihat, dengar dan dirasakan secara langsung oleh pelaku transmigran yakni S.M. Hardjo tersebut, (6) Muhajir Utomo dan Rofiq Ahmad (ed), 90 Tahun kolonisasi 45 tahun transmigrasi. Jakarta : Puspa Swara, 1997, (7) Ahmad Sahur,dkk, Migrasi, kolonisasi, perubahan sosial. Jakarta : Pustaka Grafika Kita, 1988, (8) Majalah dan Surat Khabar seperti Tiras, Gartra, Warta Caltex, Kartini dan sebagainya.

Tulisan tangan pertama yang tersebar dibanyak majalah dan penerbitan berkala sangat membantu penulis dalam pengerjaan penelitian ini. Untuk lebih jelasnya, daftar kepustakaan dibelakang dapat melengkapi informasi tentang sumber-sumber yang dipergunakan dalam rangka penelitian ini. Akhirnya tentu saja tetap disadari bahwa semua sumber yang dapat dijangkau masih jauh dari sempurna. Untuk penyempurnaan nantinya, kiranya sumber lisan akan sangat membantu. Hal tersebut didukung oleh beberapa informan yang masih hidup sampai sekarang ini.

\section{PEMBAHASAN}

\section{Proses Migrasi Etnis ${ }^{4}$}

Seperti yang telah dijelaskan pada bagian di atas bahwa daerah Pasaman Barat sebagai daerah rantau nya Minangkabau, etnis Minangkabau sebagai penduduk asli (urang asa) menganggap dua etnik yakni Mandailing dan Jawa sebagai penduduk pendatang (urang datang). Dalam cerita rakyat Rajo Sontang- misalnya menjelaskan bahwa orang pertama yang mendiami daerah tersebut berasal dari Pagaruyung, beretnis Minangkabau (Departemen Pendidikan dan Kebudayaan, 1979/1980). Kemudian, ketika maraknya perdagangan emas di Sumatera Barat kira-kira abad ke-14, orang luhak Agam, sebagian besar penduduknya menjadikan Pasaman sebagai tujuan rantau mereka.

Hal ini terjadi ketika padatnya penduduk di daerah luhak sedangkan tanah yang akan diusahakan tidak mencukupi. Penduduk luhak Agam menuju daerah-daerah yang terletak bagian utara Agam seperti Kumpulan, Bonjol, Ophir, Rao, Lubuk Sikaping, Air Bangis dan Sasak. Semua daerah ini merupakan daerah koloni penduduk luhak, dan merupakan cikal bakal sebagian besar penduduk 
Pasaman (Naim dalam Koentjaraningrat, 1984 : 64 ; Zed, 1993 : 24).

Setelah itu bermigrasi etnik Mandailing ke daerah tersebut. Tidak ada data yang pasti kapan pertama kali mereka datang ke daerah Pasaman. Sebelum munculnya gerakan Paderi di Sumatera Barat, telah terjadi interaksi antara orang Mandailing dengan orang Pasaman. Dobbin (1992) menjelaskan bahwa interaksi antara kedua sub-etnik tersebut, tidak terlepas dari hasil tambang emas dari daerah Rao. Para pedagang yang berasal dari daerah Rao melakukan barter emas dengan pedagang Mandailing di pelabuhan Natal, Batahan dan Air Bangis. Di daerah tersebut mereka saling berinteraksi satu sama lain, boleh jadi perkenalan awal antara kedua sub-etnis ini berawal dari sana.

Interaksi tersebut juga dilakukan pada kegiatan pertambangan, di mana selain Rao, Mandailing Atas (daerah yang terletak di Tapanuli Selatan) juga merupakan daerah penghasil emas. Di daerah tersebut banyak orang dari daerah Minangkabau yang ikut melakukan penambangan emas, lebih jauh Dobbin menjelaskan :

Seperti Rao, Mandailing Atas juga daerah penghasil emas, dan disini sudah ada pemukiman Minangkabau yang penting, karena banyak orang Minangkabau datang dari tempat sejauh Agam untuk bekerja di tambang. Tambang-tambang ini terletak di beberapa tempat antara Huta Nopan dan Pakantan, tetapi yang paling penting ada di dasar lembah di utara dan selatan Pakantan dan arena itu sangat dekat dengan Rao (Dobbin, 1992 :212).

Ketika terjadinya gerakan Paderi, maka terjadilah kedatangan penduduk pendatang ke daerah Pasaman. Memasuki abad ke-19, di Sumatera Barat mulai timbul suatu aliran baru yang kemudian terkenal dengan nama Gerakan Padri ${ }^{5}$. Dobbin (1992:208) menjelaskan bahwa gerakan tersebut tumbuh tidak terlepas dari kemakmuran baru yang diperoleh dari perdagangan oleh mayoritas masyarakat Minagkabau, memungkinkan lebih banyak masyarakatnya untuk naik haji serta keadaan Kota Mekkah pada tahun 1803 yang mengalami masa yang menguncangkan ; kota suci diserbu oleh pejuang-pejuang padang pasir yang tidak saja menyuarakan "kembali ke syariat", tetapi juga menyerukan tuntutan untuk kembali ke ajaran Sang Nabi dan sahabat-sahabatnya yang paling fundamental. Mereka ini adalah kaum Wahabi dari Arab Timur, dan ajaran mereka sangat terkesan bagi beberapa peziarah Minangkabau sehingga mereka juga bertekad untuk melaksanakan pembaharuan total apabila mereka tiba kembali di rumah.

Sebagai sebuah ajaran maka aktifitas untuk mendakwahkannya kepada orang merupakan tanggung jawab murid-murid tersebut. Mendakwahkan ajaran tersebut bukan saja bagi orang yang sudah tahu kepada ajaran tersebut, namun juga orang yang belum mengenal sekalipun. Dalam rangka mendakwahkan ajaran tersebutlah, Tuanku Rao bersama dengan beberapa sahabatnya seperti Tuanku Tambusai serta kemenakannya sendiri, Bagindo Suman melakukan penyebaran ajaran tersebut ke

\footnotetext{
${ }^{4}$ Bahan ini secara keseluruhan berasal dari Undri (2009), Undri (2009), Undri (2009), Undri (2006). Lebih lanjut lihat Undri, Migrasi, Perebutan Akses Tanah dan Penguatan Lembaga Adat : Resolusi Konflik Tanah di Rantau Minangkabau. Jurnal Masyarakat dan Budaya. Volume 11 Nomor 2 Tahun 2009. Jakarta : Lembaga Ilmu Pengetahuan Indonesia Pusat Penelitian Kemasyarakatan dan Kebudayaan (PMB-LIPI), 2009, Undri, Orang Pasaman : Menelusuri Sejarah Masyarakat di Rantau Minangkabau. Padang : Lembaga Kajian Gerakan Paderi (Center for Studies of the Padri Movement), Gebu Minang, Pemerintah Kabupaten Pasaman, dan Balai Pelestarian Sejarah dan Nilai Tradisional Padang, dan Undri, Konflik Tanah di Dearah Perbatasan (Studi Kasus Tiga Kelompok Etnik di Pasaman, Sumatera Barat 1930-1960) dalam http://www.geocities.ws/konferensinasionalsejarah/ undri siun, Undri, Orang Jawa di Rantau Minangkabau, Jurnal Jantra : Jurnal Sejarah dan Budaya. Volume IV nomor 7 Juni 2009 ISSN 1907-9605. Diterbitkan oleh Departemen Kebudayaan dan Pariwisata Balai Pelestarian Sejarah dan Nilai Tradisional Yogyakarta, 2009.
} 
daerah Tapanuli. Pada waktu itu, tidak tertutup kemungkinan juga ikut Raja Gadumbang, yang belajar bersama Tuanku Rao di Bonjol. Bahkan menurut Parlindungan dalam proses pengislaman yang terjadi pada tahun 1816, tentara Paderi disamping mengislamkan juga menguasai daerah Mandailing, Angkola dan Sipirok. Di Sipirok Tuanku Rao berkuasa dari tahun 1816-1818. Penguasaan daerah tersebut tidak terlepas dari usaha memuluskan untuk proses peng-islaman etiga daerah tersebut (Parlindungan, 1964 :188). Tapi, perlu diingat bahwa pada waktu peng-Islaman rakyat Mandailing tersebut ada yang dibawa ke daerah Pasaman. Di daerah tersebut mereka diberikan tanah untuk digarap. Disamping itu mereka digunakan sebagai pasukan untuk melakukan perang melawan Belanda bersama dengan kaum Paderi.

Kemudian, tahun 1915, masyarakat Minangkabau merasa terusik tatanan kehidupannya. Sebab lewat keputusan Gubernur Jendral nomor 31 tahun 1915, Undang-undang Agraria atau Domeinverklaring diterapkan. Implikasi dari kebijakan pemerintah kolonial Belanda tersebut adalah terjadinya perubahan sistem penguasaan tanah terutama penguasaan hutan, yang semula merupakan milik nagari berubah menjadi milik negara (pemerintah Hindia Belanda).

Setelah itu terjadi migrasi orang Mandailing ke daerah tersebut, penulis anggap sebagai periode yang cukup "menghebohkan”. Berdasarkan laporan surat khabar harian lokal memaparkan :

"Menurut keterangan pihak jang sangat mengetahui, selama beberapa bulan ini, dengan tjara berangsur ${ }^{2}$ telah menjelundup kedaerah ini ( Rao-penulis), lk 200 kelamin dan mengambil tanah sekehendaknya" (Haluan, 18 September 1953).

Jumlah ini terus bertambah berapa tahun kemudian, tahun 1957 tercatat lebih kurang puluhan ribu warga dari Tapanuli Selatan datang kedaerah tersebut (Haluan 5 Djanuari 1957 lihat juga Haluan 27 Djuli 1957 dan Haluan, 7 DJuni 1957). Jumlah ini merupakan jumlah terbanyak dalam sejarah migrasi orang Mandailing ke daerah Pasaman. Mereka datang dengan cara menyelundup (sembunyisembunyi) bahkan tanpa sepengetahuan pemerintah daerah yang mereka tinggalkan-dalam hal ini pemerintahan Kabupaten Tapanuli Selatan.

Datangnya penduduk pendatang tahun 1950-an ke daerah Pasaman, tidak terlepas dari kebijakan transmigrasi yang dibuat oleh pemerintah. Pada tahun 1950-an, selain meng-transmigrasikan orang Jawa ke Sumatera juga meng-transmigrasikan orang Sumatera ke daerah lain, atau dikenal dengan transmigrasi lokal. Transmigrasi yang direncanakan oleh pemerintah pada awalnya adalah memindahkan orang Jawa ke daerah Pasaman. Kemudian meng-transmigrasikan orang dari Tapanuli Selatan ke daerah Pasaman. Alasan, mengapa pemerintah menjadikan Pasaman sebagai lokasi transmigrasi tidak terlepas dari jumlah penduduk Pasaman yang relatif sedikit bila dibandingkan dengan daerah lainnya, serta keadaan alamnya sangat cocok untuk pertanian

Kedatangan para transmigrasi dari Pulau Jawa ke daerah Pasaman untuk pertama kalinya terjadi tahun 1951. Sebagai “pesanan” pemerintah pusat, maka Pemerintah Daerah Kabupaten Pasaman pada waktu itu dibawah pimpinan Bupati AM. Jalaluddin menjadikan daerah tersebut sebagai tempat domisli mereka. Pendekatan yang dilakukan oleh pihak pemerintah daerah terhadap masyarakat memang tidak berjalan mulus, bahkan masyarakat bersama dengan tokoh masyarakat di daerah tersebut

\footnotetext{
${ }^{5}$ Gerakan paderi merupakan sebuah gerakan yang hendak memurnikan ajaran Islam di Minangkabau. Aliran Pidari (bahasa lain untuk menyebut Padri) ini dikembangkan oleh orang-orang penuh cita-cita, bersedia berkorban, penuh dinamisme, kemudian sering dipaksakan secara berlebihan, terlalu picik dan kolot. Sehingga sering mendapat tantangan dari kaum adat dan juga bangsa Belanda sendiri. Cerita mengenai gerakan Paderi ini secara gambling dapat dilihat Amran, (1985:385).
} 
secara terang-terangan tidak menerima bila orang Jawa ditempatkan di daera tersebut. Sesungguhnya pihak pemerintah daerah Kabupaten Pasaman, dalam menyambut "tamunya" itu telah menyediakan lahan 32.000 hektar. Berbagai alasan dilontarkan oleh pihak masyarakat diantaranya adalah merasa takut akan kehilangan tanah apabila orang Jawa menempati daerah tersebut (Undri, $2009: 122$; Undri, 2009 :185).

Melihat kondisi lapangan, pemerintah daerah akhirnya melakukan pemindahan daerah tempat para transmigran tersebut. Pemerintah melihat bahwa daerah Pasaman bagian barat sangat cocok untuk mereka, alasannya adalah bahwa daerah tersebut masih banyak hutannya dan relatif sedikit jumlah penduduknya. Maka dengan pertimbangan tersebut mereka dibawa ke daerah tersebut, menetap dan hidup disana. Orang Jawa di daerah Pasaman bagian barat sampai sekarang masih tetap eksis.

Dengan adanya kebijakan dari pemerintah daerah Kabupaten Pasaman memindahkan transmigrasi ke daerah Pasaman bagian barat (dalam hal ini daerah Rao sering juga disebut Pasaman bagian Timur-karena memang letaknya bagian timur dari Kabupaten Pasaman), tidak "jera" dalam memindahkan penduduk ke daerah tersebut. Bagi St Bahrumsyah kemudian A.M. Jalaluddin sebagai Bupati Kabupaten Pasaman ingin melanjutkan program yang telah dirintis oleh bupati sebelumnya yakni Busrah Lubis (1947-1949) yang ingin “memindahkan” orang Tapanuli Selatan ke daerah Pasaman. Walaupun rencana yang dilakukan oleh Busrah Lubis lebih bersifat "nepotisme" karena dengan memindahkan orang Tapanuli Selatan tersebut maka keberadaan "keturunannya" akan banyak di Pasaman, sebab Busrah Lubis nota benenya adalah keturunan Batak-Mandailing (Undri, 2009 :122 ; Undri, 2009 :185).

Sesungguhnya, pada periode 1950-1960 memang -ngetren nya migrasi orang Batak keberbagai daerah, menurut Cunningham seperti yang dikutip oleh Naim, telah memperkirakan bahwa pada periode tersebut seperempat juta orang Batak Toba yang bermigrasi ke Pesisir Timur. Sampai tahun 1960, lebih 1 juta orang Batak dari semua daerah di Tapanuli (termasuk orang Batak Mandailing Islam kecuali orang Nias) telah bermigrasi ke luar daerah Batak, sebagian besar dari mereka pindah ke Sumatera Timur. Menurut pihak Pemerintah Sumatera Utara, jumlah ini mewakili sebanyak 125 persen daripada penduduk Tapanuli kecuali Nias (Naim dalam Koenjaraningrat, 1984 : 285-286).

Kedatangan orang Mandailing dari Tapanuli Selatan pada periode ini, ketika Kabupaten Pasaman dipimpin oleh Busrah Lubis. Busrah Lubis, sesungguhnya meminta kepada Bupati Tapanuli Selatan mengirimkan penduduknya ke Pasaman dan baru terealisasi pada tahun 1950-an. Busrah Lubis yang memimpin Kabupaten Pasaman periode Oktober 1947 sampai Desember 1949 adalah orang yang berasal dari keturunan Mandailing itu sendiri. Sehingga tidaklah heran bila dia mengingginkan adanya "keturunan" dia untuk mendiami daerah Pasaman. Hal ini didukung oleh adanya perintis terdahulu sebelum mereka seperti keluarga Busrah Lubis yang mendiami daerah Pasaman.

Kemudian diikuti bermigrasinya etnik Jawa ke daerah tersebut. Diceritakan sebelumnya bahwa J.H.Ballot sebagai Gubernur Sumatra's Westkust pada tahun 1910 punya angan-angan untuk memindahkan orang Jawa ke daerah Pasaman. Alasan pemindahan orang Jawa ini adalah secara khusus melihat lebarnya tanah kosong yang tidak dikerjakan oleh masyarakat setempat dan subur. Dalam 0 etoesan M inangkabau : Sasaran Penghoeloe M edan Ra'jat berbunyi :

"Agar dapat pemandangan dan pertimbangan kepada fihak pemerintah tinggi, bahwa ada soedah angan-angan dari fihak pemerintah, akan memindahkan orang-orang djawa ke M.K [Minangkabau],teroetama karena melihat lebarnja tanah kosong jg [juga] tinggal dari tahoen ke 
tahoen (tidak dikerdjakan oleh anak negeri) ijalah antara Sasak dengan Ajer Bangis ; tanah disini, soengoeh-soengoeh lebar, dan rata, maaloemlah tanah Pasisir (pinggir laoet)" (Oetoesan Minangkabau : Sasaran Penghoeloe Medan Ra'jat tanggall 27 Maart 1939. Nomor 1 Tahoen ke 5).

Secara umum tidak terlepas dari pengaruh kebijakan pemerintah Belanda tentang politik etis. Politik etis atau lebih dikenal dengan politik balas budi tidak terlepas dari sebuah tulisan c. Th.van Deventer, anggota Raad van Indie berjudul Een Eereschuld (hutang budi) yang dimuat dalam majalah De Gids yang terbit pada tahun 1899. Tulisan tersebut membeberkan tentang kemiskinan di Pulau Jawa serta kaitannya dengan cultuur stelsel dan pelaksanaan kerja paksa oleh pemerintah kolonial Hindia Belanda. Van Deventer dalam tulisan itu mengimbau agar pemerintah Belanda melakukan upayaupaya yang dapat membantu memperbaiki kehidupan rakyat di Pulau Jawa yang kemudian dikenal dengan Politik Etika (etische politic).

Selain program memajukan pendidikan pribumi, perbaikan irigasi, politik etis juga membuat program pemindahan orang dari daerah yang berpenduduk padat ke daerah yang jarang penduduknya, atau dikenal juga dengan program transmigrasi. Terutama pemindahan orang Jawa dari pulau Jawa ke luar pulau Jawa. Pemindahan orang Jawa ini, sebelum direncanakan ke Sumatera Barat khususnya ke Pasaman sudah berlangsung pada daerah lain. Pada tahun 1905, dipindahkan sebanyak 155 keluarga petani dari Kedu dipindahkan ke desa baru yang didirikan dekat Gedong Tataan sebelah selatan dari Way Sekampung di Lampung Selatan. Pemilihan lokasi dan pemindahan para kolonis dilaksanakan oleh H.G.Heyting yang ketika itu menjabat Asisten Residen Kedu (Hardjono (Penyunting), 1982 :34).

Sebuah pemukiman kecil didirikan di Bengkulu pada tahun 1909 sedangkan pada tahun 1922 sebuah pemukiman lebih besar yang diberi nama Wonosobo didirikan dekat Kota Agung di Lampung Selatan. Rencana memindahkan orang Jawa ke Sumatera Barat khususnya ke daerah Pasaman pada tahun 1910, gagal karena orang Jawa yang mau dipindahkan ke Sumatra Barat mau berdiri sendiri dan tidak mau tunduk kepada kepala Laras yang ada di daerah tersebut, seperti yang dinukilkan dalam surat khabar Oetoesan Minangkabau : Sasaran Penghoeloe Medan Ra'jat sebagai berikut ini:

Di antara Toeankoe Laras jang soedah diadjak oleh toean Gouverneur Ballot, ada jang sangat setoedjoe atas maksoed toean Gouverneur itoe, dan memintak soepaja dapat Kolonisten Djawa itoe dipindahkan jang pertama ke M.K.[Minangkabau] ini (di negeri L.S [Lubuk Sikaping], dimintak oleh Toeankoe Laras itoe SERIBOE ORANG, tetapi segala ongkos, orang-orang itoe dari Djawa datang ke M.K diantanggoeng oleh Regeering, biarlah sesampainja di LS, nanti negeri menanggoeng makanja (berarti padi oentoek satoe tahoen boeat orang Djawa jang baharoe datang itoe di tanggoeng oleh negeri LS.

Tetapi Toenkoe Laras itoe memintak soepaja segala orang Djawa jang datang itoe, dibawah parentah Toeankoe Laras, tidak boleh mereka itoe berdiri sendiri; zelfstaandig mengadakan kepala sendiri jang mardeka, melainkan segala hal ichwal mereka itoe dibawah Tilikkan dan siasat Toeankoe Laras. Moefakat poetoes pembitjaraan soedah, toean Besar Gouverneur J.Ballot, sangat berbesar hati, melainkan fasal orang Djawa itoe, moesti dibawah parentah Toeankoe Laras, akan dipertimbangkan dan diberi tahoekan kepada Regeering.

Selain dari itoe, sebabnja maka Toeankoe Laras memintak soepaja Kolonisten (Java) itoe, dibawah taaloek dan perentah Toeankoe Laras, karena menoeroet adat istiadat M.K, tidak dapat mereka itoe, berdiri sendiri, karena tanah nan bapoenja, rimba nan baoelajat, 
tjoepak ke dialiah oerang penggaleh, djalan ke diandjak oerang laloe, djadi pantangan dan meroesak adat istiadat M.K. Begitoe djoega menoeroet oendang-oendang adat M.K dimana langit didjoendjoeng, boemi ditoenggoei, aer di sawoek ranting dipatah ; adat negeri itoe, moesti ditoeroet ( 0 etoesan M inangkabau : Sasaran P enghoeloe M edan Ra'jat. Tahoen 5. nomor 1.27 Maart 1939).

Tokoh masyarakat di daerah tersebut telah melakukan penyambutan kedatangan orang Jawa ini, mereka telah mengumpulkan 5000 pikul padi untuk mereka. Walaupun telah dikumpulkan padi sebanyak itu, orang Jawa tetap keberatan terhadap tawaran yang berasal dari Tuanku Laras dimana mereka berada di daerah tersebut dan tunduk kepada dia.

Delapan boelan kemoedian itoe, sedang Toeankoe Laras dengan penghoeloe-penghoeloe bersiap menjediakan PADI, sehingga soedah terkoempoel hampir 5000 pikoel, datang chabar dari toean Gouverneur J.Ballot bahwa, atas maksoed memindahkan orang Djawa ke negeri Toeankoe, tidak dapat diteroeskan karena orang Djawa itoe, merasa KEBERATAN, dibawah parentah Toeankoe Laras, melainkan mereka itoe maoe pindah ke M.K membawa kepala sendiri dan kepala itoe, maoe teroes dibawah parentah, Europeesch BB [Binenland Bestuur]. Ambtenaar sadja, tidak maoe dibawah parentah Toeankoe Laras.

Dalam Oetoesan Alam Minangkabau nomor 2, moeka 21 terseboet :.......atas maksoek [d] memindahkan orang Djawa kenegeri Toean koe, tidak dapat diteroeskan karena orang Djawa itoe, merasa KEBERATAN dibawah Toeankoe Laras, melainkan mereka itoe maoe pindah ke M.K [Minangkabau] membawa kepala sendiri dan kepala itoe maoe teroes dibawah perentah Europeesch B.B [Binelanden Bestuur] Ambtenaar sadja......". Disini njata poela kepada kita bahwa kepindahan mereka itoe beloem didorong oleh keperloean hidoep jang amat sangat, meskipoen di Djawa mereka itoe ditjaboet poela disana sini. (Oetoesan Alam Minangkabau Tahun I Nomor 5 Maart $1939: 71)$.

Angan-angan J.H.Ballot sebagai Gubernur Jendral Sumatra's Westkust untuk memindahkan orang Jawa ke Sumatera Barat menjadi perhatian bagi anggota Minangkabau Raad (Dewan Minangkabau). Berdasarkan berita Soeara Minangkabaoe bahwa kedatangan orang Jawa kedaerah Sumatera Barat dibicarakan dalam Minangkabau Raad, selain masalah tersebut merupakan masalah anak nagari di Sumatera Barat juga keinginan yang kuat dari Nawi gelar Madjo Batoeah sebagai Kepala Nagari Lubuk Sikaping dan Abdoellah gelar Toeankoe Radjo Moedo sebagai Kepala Nagari Air Bangis, kedua orang ini duduk dalam Minangkabau Raad itu sendiri (Soeara Minangkabaoe Tahoen 1 nomor 1 Augustus 1938).

Dalam sidang Minangkabau Raad tersebut dibicarakan, apakah betul pemerintah sudah bersedia memberikan tanah dalam bahagian Ophir (Pasaman) kepada kolonisatie orang Jawa. Apakah pemerintah sudah memikirkan dan mempertimbangkan bahwa nanti Minangkabau sendiri akan kekurangan tanah karena penduduknya semakin hari semakin bertambah banyak (Undri, 2009 :102103). Kekuatiran tersebut dilandasi dengan alasan bahwa di Minangkabau yang mana negerinya sendiri sudah sempit oleh penduduknya, tanah-tanah yang terluang tidak pula seberapa banyak, seperti di daerah Ophir, Rao dan Batang Hari yang tidak begitu luas serta tidak pula banyak tanah yang subur yang bisa dijadikan sawah karena ketiadaan air. Mereka kuatir kalau orang Jawa sudah berkembang biak dan dalam bidang ekonomi mereka itu dapat mengalahkan ekonomi anak nagari yang asli. Kata pepatah adat Minangkabau, "Alah limau dibinalu" (kalah limau karena binalu). Adat Minangkabau tidak menolak orang datang (orang dari luar) datang berusaha dan menumpang hidup berusaha ke negerinya, boleh juga diberi tanah yang akan diusahakan. Tetapi adat itu ada pula ikatannya : hendaklah orang itu, terbang menumpu hinggap mencekam, masuk menjadi orang Minangkabau dengan menurut 
syarat yang berlaku. Dalam hal itu ada pula terselip satu kerugian dari orang Minangkabau yaitu ; dalam daerah Ophir itu ada beberapa onderneming yang mempergunakan kuli-kuli, jika dalam daerah itu sudah banyak orang Jawa, niscaya tuan-tuan onderdeming tentu akan mengambil kuli-kuli Jawa saja karena orang Jawa lebih rajin dan tabah bekerja dari Orang Minangkabau. Kekuatiran terdesaknya Orang Minangkabau oleh orang Jawa, padang-padang dan hutan-hutan cadangan dan rimba-rimba ulayat orang Minangkabau yang tidak begitu luas dibandingkan dengan banyaknya orang pribumi (Oetoesan Alam Minangkabau tahoen 1 no. 5, Maart 1939 : 70-71).

Migrasi etnik Jawa ke daerah Pasaman juga tidak terlepas direkrutnya sebagai buruh perkebunan. Hal ini tidak terlepas dari kemenangan partai liberal yang terdiri dari kaum bermodal dipanggung politik Belanda sejak tahun 1848. Menuntut perlu adanya sistem perekonomian liberal atau bebas dari proteksi pemerintah (Kartodirdjo, 1990 :17-21). Hal ini menyebabkan terbukanya peluang bagi kaum swasta, untuk menginvestasikan modalnya dalam aktifitas perekonomian di Indonesia. Akibatnya sejak tahun 1908 sistem tanaman paksa dihapuskan di Sumatera Barat, untuk kemudian dibuka bagi kaum penanam modal untuk menanamkan modalnya di Sumatera Barat.

Oleh sebab itulah daerah Pasaman sebagai salah satu bagian dari daerah yang ada di Sumatera Barat juga menjadi incaran para pemilik modal tersebut. Kedatangan pemilik modal ke daerah Pasaman disebabkan karena daerah tersebut sangat strategis untuk dikembangkan, karena Pasaman mempunyai daerah yang cukup luas dan subur untuk lahan perkebunan. Di samping adanya pelabuhan-pelabuhan kecil sebagai sarana penunjang untuk proses distribusi hasil. Pelabuhan tersebut adalah pelabuhan Sasak dan Air Bangis. Kedua pelabuhan ini merupakan pelabuhan tradisional sejak dulunya (Kato dalam Nagazumi (Penyunting), 1986:77-115).

Kedatangan pemilik modal di Pasaman ditandai dengan munculnya perusahaan perkebunan N.V.Syndicaat Ophir tahun 1911, yang mendapatkan secara erfpacht di onderafdeeling Ophir, dengan luas $3.370 \mathrm{bau}$. Perusahaan ini menyewa tanah sebesar f.1 dalam satu bau pertahun. Sampai tahun 1915 ada sebanyak 5 perusahaan yang telah menanamkan modalnya di Pasaman. Kelima perusahaan tersebut adalah N.V.Syndicaat Ophir, N.V. Sumatera Thee Mij, N.V.Tapanoeli, N.V.Talamaoe dan satu perusahaan belum punya nama yang dipimpin oleh C.Knegtmans (Asfahrizal, 1996 : 342).

Pada tahun 1927 muncul beberapa buah perusahaan yang menanamkan modalnya di Pasaman. Perusahaan tersebut adalah N.V.Cultuur Maatschappij dan N.V. Air Bangische Cultuur Maatschappij. Pada tahun 1928 perusahaan swasta Belanda ini telah menanamkan tanaman kopi dilahan yang telah disewanya. Tanaman kopi yang ditanam pada tahun 1928 sebanyak 298. Kemudian penanaman luas tanaman kopi setiap tahun mengalami pasang surut. Pada tahun 1932 luas tanaman kopi dikebun Ophir mencapai 3002 hektar, sedangkan pada tahun 1935 luas tanaman kopi menurun menjadi 1.635 hektar. Akibat produksi kopi yang mengecewakan pada akhir tahun 1935 di onderneming Ophir Pasaman dan menurunnya harga kopi, yaitu hanya f.17,50 sampai f.18 di Pasaran, maka pengusaha onderneming yang menanamkan modalnya di onderneming Ophir mengalihkan usahanya ketanaman komersil lainnya. Pengalihan usaha tanaman ini dilakukan sesuai dengan perkembangan yang terjadi di Indonesia pada masa itu. Perkembangan dan kemajuan perkebunan kelapa sawit di Sumatera Timur, juga telah mengilhami pengusaha perkebunan Ophir di Pasaman untuk mengalihkan usahanya keperkebunan kelapa sawit. Ditambah lagi meningkatnya kebutuhan akan bahan baku untuk pembuatan sabun di Eropha, sehingga pada tahun 1936 salah satu perusahaan yang menanamkan modalnya di 
Ophir yaitu perusahaan N.V. Cultuur Maatschaappij Ophir mengalihkan usahanya ke perkebunan kelapa sawit (Asfahrizal, $1996: 32$ ).

Untuk tenaga kerja perusahaan ini memanfaatkan buruh-buruh perkebunan kopi Ophir, karena perkebunan kopi telah dihentikan pemeliharaan dan proses produksinya. Tenaga kerjanya terdiri dari buruh bebas Jawa (vrije Java) dan buruh lepas (losse Arbeiders) yang umumnya adalah suku Melayu. Menurut laporan kamar dagang Belanda di Padang, pada akhir tahun 1935 buruh Jawa yang bekerja di perusahaan N.V.Cultuur Maatschappij Ophir sebanyak 1.710 orang, sedangkan buruh lepas sebanyak 142 orang. Berarti pada awal tahun 1936 buruh yang bekerja diperusahaan ini adalah sebanyak 1.852 orang. Buruh inilah yang dimanfaatkan oleh perusahaan Belanda untuk mengerjakan pembangunan kelapa sawit Ophir.

Selain itu keberadaan etnik Jawa di daerah Pasaman juga berasal dari Suriname. Keberadaan orang Jawa di Suriname tidak terlepas dari perekrutan oleh perusahaan-perusahaan milik Belanda di Suriname. Mereka dijadikan sebagai buruh murah. Selain dari Jawa, buruh murah tersebut diambil dari India dan Afrika (Koriun dan Idrus F. Shahab dalam Majalah Tiras, nomor 32, 5 September 1996 : F-G). Mereka berasal dari berbagai daerah Kabupaten, seperti Malang, Blitar, Cilacap, Ponorogo serta beberapa daerah lainnya (Alimin, dalam Majalah Warta Caltex nomor.34 tahun 1993 : 30). Pada awalnya mereka banyak yang tidak tahu kalau tujuan bekerja ke Suriname. Kondisi kehidupan yang sengsara di Jawa akibat Tanam Paksa (1830-1870) membuat sebagian mereka berpikir untuk bisa keluar dari Jawa dengan cara apapun.

Pada bulan April 1953, rombongan berangkat bersama Djawatan Transmigrasi ke Sumatera Tengah di Bukittinggi. Mereka melakukan pembicaraan dengan Gubernur Roeslan Moelyohardjo dan disepakati bahwa tanah tempat para repatrian tersebut terletak di Kenagarian Air Gadang Kecamatan Pasaman seluas 2.500 hektar. Rombongan tersebut kemudian berangkat ke Pasaman dan menemui ninik mamak cerdik pandai Kenagarian Air Gadang. Mereka antara lain Datuak Jolelo (Camat Pasaman), Sutan Laut Api (Kepala Nagari Air Gadang) dan Sutan Bandaro Ali Imran (Koordinator Wedena). Diwakili Kepala Nagari dijelaskan, bahwa penduduk Nagari Air Gadang bersedia menerima penduduk pendatang dan akan dianggap sebagai anak kemenakan.

Kedatangan orang Jawa ke daerah Pasaman sebetulnya diserahkan tanah untuk digarap mereka. Penyerahan atas tanah tersebut dilakukan oleh ninik mamak yang ada di Wilayah Pasaman Kabupaten Pasaman Barat. Ninik mamak yang menyerahkan tanah kepada para transmigran tersebut adalah sebagai berikut: (1) Sutan Laut Api, (2) Sutan Maindo, (3) Magek Putih, (4) Radja Mangkuto, (5) Sutan Pangaduan, (6) Datuak Radjo Sampono, (7) Datuak Muda Bumi, (8) Datuak Paduko Indo, (9) Datuak Paduko Indo, (10) Datuak Pandji Alam, (11) Datuak Sati, (12) Datuak Bantaro Raso, (13) Datuak Djalelo Garantau, (14) Datuak Djalolo St.Umpai, dan (15) Sutan Kebesaran (Surat Penjerahan tanah oleh ninik mamak di wilayah Pasaman Kabupaten Pasaman Barat tahun 1953).

Setelah dilakukan penyerahan tanah kepada para transmigran maka dilakukanlah pembukaan perkampungan bagi mereka. Khusus pembukaan perkampungan repatrian Suriname ditangani oleh Yayasan Tanah Air (YTA) dengan membentuk divisi-devisi kerja yang bertujuan agar perencanaan kerja per bidang tidak tumpang tindih. Devisi-devisi itu adalah sebagai berikut : (1). S.M.Hardjo sebagai ketua YTA langsung menjadi pimpinan proyek pembukaan perkampungan. (2). F.N.Soemopawiro sebagai administrator, urusan tata usaha serta urusan pendidikan dan pengajaran. (3). Doerat sebagai kepala urusan penyelenggaraan pekerjaan bidang pertanian, perikanan dan 
pembibitan. (4). L.Sirtja sebagai kepala urusan perdagangan, took, gudang dan krani. (5). Koesman Soekimanan sebagai kepala urusan pusat penggergajian kayu (somel). (6). M.Bledoeg sebagai kepala urusan bidang bengkel, kenderaan bermotor dan listrik. (7). Parmin sebagai kepala pembangunan rumah dan bangunan. (8). A.J. Senawi sebagai kepala urusan kesehatan. (9). S.Poentjopawiro sebagai kepala urusan keamanan kampung yang membawahi bidang pendataan rumah dan urusan antar warga, (10). Soeratman sebagai kepala urusan admistrasi yang membawahi bidang pembukaan umum, keuangan, honor pengurus, krani, ekspedisi, pos dan juru ketik, dan (10). S.A.Taguan Hardjo sebagai kepala urusan pemetaan dan pengukuran serta gambar (Laporan Umum Jajasan Tanah Air Tahun 1954, Lingkin Baru (Tongar);15 Mei 1955 : 3-4). Sampai tahun 1968 telah ada 9 perkampungan transmigran di Pasaman Barat dengan penempatan sejumlah 2.069 kepala keluarga, atau 8.725 jiwa. Hampir separo (46\%) berasal dari Jawa Tengah dan daerah Yogyakarta, $29 \%$ dari Jawa Timur, $8 \%$ dari Jawa Barat dan $14 \%$ dari repatrian Suriname.

Ada tiga faktor pokok yang selalu disebut-sebut yang memungkinkan mereka ditempatkan di Pasaman Barat, pertama daerahnya yang relatif luas. Kedua, penduduknya yang relatif jarang. Ketiga, pada awalnya ada semacam kesedian dari penduduk setempat sendiri menerima mereka, dengan menyerahkan tanah pusaka (tanah ulayat) mereka sendiri untuk keperluan transmigrasi namun akhirnya penduduk setempat merasa keberatan atas keberadaan penduduk pendatang (para transmigran). Sampai tahun 1968 tidak kurang dari 38.000 HA tanah ulayat yang telah diserahkan oleh ninik mamak/pemuka masyarakat setempat untuk keperluan transmigrasi.

Kedatangan orang Jawa ke daerah Pasaman memberi warna tersendiri bagi daerah tersebut, sebab sebelum kedatangan orang Jawa, orang Tapanuli (dalam hal ini Batak Mandailing) dan Minangkabau sebelumnya sudah menempati daerah tersebut. Sampai tahun 1974, jumlah orang Jawa di Pasaman Barat yakni berjumlah 12,799 jiwa orang. Jumlah ini menempati urutan ketiga setelah etnik Minangkabau dan Tapanuli.

\section{Daerah Multietnis}

Dalam setiap komunitas hubungan sosial sudah barang tentu terjadi antara orang-orang yang ada didalamnya, demikian pula dengan daerah Pasaman Barat dimana tempat dilaksanakan penelitian ini. Hubungan sosial yang terjadi di tengah-tengah masyarakat diwujudkan dengan interaksi yang dilaksanakan sehari-hari oleh individu dengan individu kelompok dengan kelompok, individu dengan kelompok dan dilaksanakan antara tetangga antara etnik dengan orang luar dan lain sebagainya.

Perkawinan campuran yang terjadi antara etnik yang berlainan tentu membawa perubahan dari masing-masing etnik terutama menyangkut keyakinan dan nilai budaya yang dianut oleh masyarakat dan juga memperluas jaringan kekerabatan. Dapat dikatakan perkawinan campuran adalah bahagian dari terjadinya interaksi. Perkawinan adalah ikatan yang sah antara laki-laki dengan perempuan dalam membentuk rumah tangga atau keluarga yang nantinya akan melibatkan kerabat masing-masing pihak.

Dalam persoalan ini dapat kita lihat sejarah daerah Jambak, ${ }^{6}$ sebuah daerah yang ada di Kabupaten Pasaman Barat yang ditempati oleh etnik Jawa, Minangkabau dan Batak. Desa Jambak sebenarnya adalah daerah lingkungan hukum adat Minangkabau yang dahulunya merupakan bahagian dari pemerintahan Yang Dipertuan Parit Batu yang menguasai daerah Pasaman barat. ${ }^{7}$ Yang Dipertuan Parit Batu merupakan puncak pimpinan dari beberapa nagari secara hukum adat Minangkabau, begitu juga daerah Jambak yang merupakan bahagian dari Nagari Lingkung Aur. 
Cerita semacam ini bagi orang tua-tua yang penduduk asli Pasaman Barat mengakui hal tersebut. Daerah Jambak dahulunya tinggal beberapa warga untuk membuka lahan, mereka adalah orangorang yang datang dari daerah yang berdekatan dengan lokasi ini yaitu dari Labuh Lurus dan Parit Batu. Orang -orang itu adalah cucu kemenakan dari Tuangku Jambak yang mempunyai suku Jambak. Seperti yang telah kita ketahui Pasaman adalah daerah rantau dari Minangkabau. Dengan tinggalnya warga yang mempunyai suku Jambak di sini maka daerah ini dinamakan dengan Kampung Jambak.

Pada waktu pemerintahan Belanda di Indonesia maka daerah- daerah yang potensial mereka pergunakan untuk area pertanian dan perkebunan seperti perkebunan gula di Jawa, cengkeh di Sulawesi, teh di Jawa dan lain sebagainya yang berguna untuk meraih keuntungan bagi Belanda untuk memenuhi kebutuhan pasar Eropa. Demikian juga halnya dengan daerah Pasaman Barat, maka di sini ditanam perkebunan kelapa sawit. Perkebunan ini meliputi daerah Jambak, Kinali, Rimbo Binuang, kesemuanya berjumlah 10 ribu hektar lebih. Untuk mendapatkan buruh dan pekerja bagi Belanda mereka mendatangkan tenaga dari Jawa yang waktu itu dinamakan dengan buruh kontrak. Perkebunan ini oleh rakyat Pasaman dinamakan daerah Bukit Nilam karena banyak terdapat pohon Nilam, tetapi Belanda menamakan dengan perkebunan Ophir.

Sampai sekarang perkebunan ini tetap bernama perkebunan Opir. Untuk tempat tinggal buruh kontrak maka dibentuk tempat-tempat pemukiman yang dinamakan dengan Afdeling. Afdeling I adalah daerah Jambak sekarang ditambah dengan Ophir sekarang, Afdeling II adalah daerah Bandarjo dan Afdeling III adalah Sindomulyo dan Kinali. Sedangkan warga Jambak yang bermukim di sini pergi kembali kedaerah asal mereka karena tanah mereka dikuasai oleh pemerintah Belanda. Perkebunan sawit Belanda ini maju sangat pesat sekali, untuk pengangkutan kelapa sawit maka digunakan kereta api ke Pantai Sasak yang nantinya dibawa dengan kapal laut.

Setelah Jepang masuk di Indonesia maka Belanda tidak lagi berkuasa atas Indonesia begitu juga dengan perkebunan tersebut. Masa pendudukan tentara Jepang perkebunan kelapa sawit ini tidak terurus lagi dengan baik, setelah Jepang kalah dengan sekutu maka semua milik Belanda di Indonesia dikembalikan kepada Belanda. Ketika Indonesia sudah merdeka, selanjutnya terjadilah agresi I dan II. Melalui konferendsi Meja Bundar di Den Hag Belanda maka diadakan persetujuan bahwa seluruh milik Belanda di Indonesia dikembalikan, hal ini punya pengaruh terhadap perkebunan Ophir Pasaman. Para buruh kontrak dari Jawa ini tetap tinggal di sini terutama afdeling II dan III. Sedangkan afdeling I yang meliputi daerah Jambak dibeli oleh Departemen Pertahanan dan Keamanan (Dephankam) serta daerah perkebunan sawit itu sendiri, oleh Dephankam digunakan sebagai daerah transmigrasi Angkatan Darat yang nantinya ditempati oleh para pensiunan ABRIAD (Angkatan Bersenjata Republik Indonesia Angkatan Darat).

Perkebunan kelapa sawit yang ditinggalkan Belanda tadi sudah menjadi rimba belantara. Sekarang tanahnya sudah merupakan milik Dephankam yang dinamakan dengan tanah Pancang Merah karena milik pemerintah. Dengan tinggalnya para pensiunan ABRIAD di sini maka mulailah

${ }^{6}$ Bahan tentang Jambak berasal dari Uripsyah, 1990. Lebih lanjut lihat Yadri Uripsyah, 1990. Integrasi dan Konflik Etnik di Pemukiman Baru : Studi Kasus Desa Jambak Kabupaten Pasaman. Skripsi S1. Padang : Fakultas Sastra Universitas Andalas.

${ }^{7}$ Sangat disayangkan data mengenai jumlah penduduk antaretnik belum diperoleh dengan baik dilapangan. 
bercampurnya beberapa etnik pada lokasi ini baik itu etnik Jawa, Minangkabau, dan Batak Mandailing.

Mereka mulai menanami palawija dan membikin persawahan, karena daerah ini potensial untuk perkebunan kelapa sawit maka oleh pemerintah mulai tahun 1981 di mulai membuka perkebunan baru pada tahan Pancang Merah ini. Setelah mengadakan perjanjian dengan pihak Dephankam maka proses penanaman kembali kelapa sawit dilaksanakan oleh PTP VI. Perjanjian dengan Dephankam tersebut berisikan bahwa perkebunan ini adalah pola sistem PIR (Pola Inti Rakyat) dan para petaninya harus $35 \%$ pensiunan ABRI. Mulai dari itu terbentuklah perkebunan kelapa sawit Pasaman.

Akibat terbukanya perkebunan disini maka berdatanganlah orang-orang dari segala penjuru baik itu dari Sumatra Barat sendiri maupun dari lokasi transmigrasi yang adi di Pasaman ini. Selanjutnya penambahan pemukim yang didatangkan dari Kodam Siliwangi Diponegoro dan Kodam Brawijaya. Maka lengkaplah keragaman penduduk di sini dan dinamakan dengan pemukiman baru karena tidak terdapat lagi penduduk asli. Warga yang menetap di sini sekarang semuanya adalah pendatang dari daerah lain, yang merupakan pemukim baru. Pada saat sekarang ini dari orang-orang ada yang mengatakan bahwa nama Jambak itu adalah singkatan dari Jawa Minang dan Batak Mandailing.

\section{Faktor Pendorong dan Penghambat Interaksi Antar Etnik}

Ikatan kekeluargaan atau kekerabatan sangat kuat dalam mendorong terjalinnya interaksi. Menurut Suparlan (1982 :7-9), ikatan kekeluargaan atau kekerabatan adalah suatu pengelompokan atas sejumlah orang yang dihubungkan dengan yang lainnya menurut sistem kekerabatan yang mencakup identitas dan peranan yang digunakan oleh individu - individu dalam institusi sosial mereka.

Berbicara masalah sistem kekerabatan masyarakat di daerah Pasaman Barat sama halnya dengan sistem kekerabatan atau kekeluargaan di Minangkabau yaitu berdasarkan kepada sistem matrilineal atau garis keturunan ibu. Mengenai struktur keluarga dalam masyarakat Minangkabau umumnya dan didaerah tersebut khususnya mempunyai beberapa tingkatan yaitu kaum, paruik dan suku (Naim et.al 1968 :57 ; Bachtiar dalam Koentjaraningrat, 1989 :348-385).

Tingkatan tersebut sesungguhnya memperlihatkan kepada kita bahwa manusia hidup didunia merupakan suatu kebersamaan, atau dengan istilah lainnya adalah manusia sebagai makhluk sosial. Manusia sebagai makhluk sosial tidak hidup sendiri melainkan bersama-sama dengan tingkatan ikatan seperti diatas tersebut. Mereka saling membutuhkan dalam kehidupan sosial, karena pada dasarnya manusia merupakan makhluk individu dan sekaligus makhluk sosial yang membutuhkan interaksi dengan orang lain untuk memenuhi kebutuhan hidupnya terutama hubungannya dengan suatu keluarga. Ada banyak hal yang menyebabkan hubungan kekeluargaan di daerah pedesaan sangat erat seperti halnya di daerah Pasaman Barat antara penduduk asli dengan penduduk pendatang. Hal tersebut dibingkai oleh adanya kesamaan status sebagai penduduk asli, sesuku, kesamaan mata pencaharian, persepsi dan masih kuatnya adat istiadat di daerah tersebut.

Dalam kehidupan sehari-hari, hubungan diantara penduduk asli begitu eratnya seperti terlihat pada penyelenggaraan perkawinan, kematian, hari raya, dalam hal bertetangga misalnya, mereka saling membantu apabila ada tetangga yang kurang mampu. Kesemua tersebut mereka lakukan secara bersama-sama. Kegiatan tersebut secara tidak langsung telah membentuk prilaku masyarakat untuk membentuk suatu ikatan kebersamaan diantara mereka.

Dalam hal hubungan diantara keluarga yakni antara orang tua dan anak, pengaruh keberadaan 
perkebunan sangat kuat. Dimana pada dasarnya keluarga merupakan kelompok sosial yang terpenting dalam masyarakat. Secara konseptual menurut Koenjraningrat (1992 :34) menunjukkan fungsi pokok dari keluarga dalam suatu masyarakat yakni merupakan kelompok dimana individu pada dasarnya dapat menikmati bantuan utama dari sesamanya serta keamanan dalam hidup, dan merupakan kelompok individu itu sewaktu ia sebagai anak-anak, masih belum berdaya sehingga mendapatkan pengasuh dan permulaan pendidikannya.

Kemudian salah-satu faktor yang memberikan arah terjadinya proses interaksi yaitu pendidikan dan pengalaman dari individu yang berintegrasi. Melalui analisa dari beberapainforman maka diketahui dengan adanya pendidikan yang dimiliki penduduk maka pemahaman-pemahaman terhadap etnik lainnya yang di dapatkan dari pelajaran-pelajaran bangku sekolah dahulu, membaca di media masa, pendidikan informal melalui kursus, organisasi dan lain sebagainya. Bagi anak-anak dan remaja yang masih menempuh bangku pendidikan sudah barang tentu pengalaman dan pengetahuan tentang sukusuku bangsa dapat dipahami mereka dan tidak asing bagi mereka lagi. Dengan semakin tingginya pendidikan dari masyarakat maka semakin banyak pemahaman dan ruang lingkup pemikiran terhadap orang lain. Bagi anak-anak sekolah sudah terbiasa bergaul dan menyesuaikan diri dengan orang lain diluar etniknya. Sosialisasai anak-anak yang terjadi pada lingkungan majemuk terjadi maka proses interaksi dapat terjadi dengan cepat.

Pengalaman dari individu juga menyebabkan mudah tercapainya kebersamaaan dan tidak menganggap asing etnik lainnya. Penduduk Desa Jambak mayoritas orang tua mereka adalah bekas anggota ABRI. Bagi anggota ABRI sudah terbiasa bergaul dengan orang lain juga diluar etnik individu itu sendiri, mereka sudah terbiasa dengan orang luar waktu bertugas dahulu. Sudah barang tentu pemahaman terhadap tempat-tempat yang pernah didatangi mempengaruhi terhadap proses adaptasi diri dalam lingkungan tersebut. Hingga pada Desa Jambak tidak asing baginya lagi dan mudah untuk bekerja sama dengan orang lain. Di lain pihak sebagai anggota ABRI(Angkatan Bersenjata Republik Indonesia) yang satu kesatuan yang utuh maka interaksi antara mereka sudah terjalin sangat kuat sekali. Pengaruhnya terhadap proses interaksi di Desa Jambak sangat kuat apalagi mereka semua pensiunan ABRI dan sudah terbiasa dengan disiplin yang utuh diantara mereka.

Sebagai anggota masyarakat Jambak pensiunan ABRI adalah keluarga yang dominan dibandingkan dengan penduduk yang berasal dari petani. Kedominan itu akan membawa pengaruh terhadap lainnya, sebab proses interaksi itu cenderung mengarah pada masyarakat yang dominan. Adanya tempat tinggal yang bercampur baur antara etnik yang berlainan di tempat pemukiman tanpa ada pengelompokan berdasarkan etnik mempermudah terjadinya interaksi. Desa Jambak tidak ada yang namanya kampung Jawa, kampung Batak, dan lainnya. Hal ini mengurangi jarak sosial antara penduduk yang berlainan suku bangsa. Dapat dikatakan pola pemukiman Transad (Transmigrasi Angkatan Darat) dan pola pemukiman PIR (Perkebunan Inti Rakyat) merupakan faktor mempercepat proses pembauran. Hubungan antara etnik selalu yang terjalin dan saling ketergantungan dan membutuhkan akibat hidup berdampingan antar penduduk.

Di Desa Jambak agama Islam adalah agama yang mayoritas dianut penduduknya. Masjid dan mushalla adalah tempat ibadah yang bersama dan tempat terjalinnya interaksi antar penduduk. Adanya perasaan seagama dan sering terlibat dalam suasana ibadah mempermudah terjalinnya integrasi antar penduduk. Begitu juga halnya dengan agama lain seperti Kristen gerejalah tempat ibadah mereka dan juga tempat menjalin persatuan antara mereka. Bukan itu saja, masuknya penduduk dalam berbagai 
organisasi maka hal ini juga akan mempercepat terjadinya interaksi, karena setiap organisasi bertujuan untuk kepentingan anggotanya. Organisasi seperti PKK, Karang Taruna, FKPPI, Kelompok Tani, PEPABRI merupakan sarana untuk menyatukan para anggotanya. Mereka terikat akan peraturanperaturan yang ditetapkan bersama dan keterikatan itu akan menyatukan mereka. Sudah barang tentu mereka juga terdiri dari bermacam etnik didalamnya, berarti interaksi antar etnik juga dipengaruhi oleh adanya wadah organisasi.

\section{Pengaruh Interaksi}

Dengan terjadinya hubungan sosial dalam masyarakat majemuk melahirkan perubahan pola kebudayaan dari masing-masing etnik, terjadi pada : bahasa dan orientasi nilai budaya dari masingmasing etnik tersebut. Dalam segi bahasa terjadi perubahan yang sangat pesat, terutama dalam komunikasi yang melibatkan dua atau lebih etnik yang ada. Terdapatnya percampuran bahasa daerah yang melatar belakangi budaya masing-masing etnik, dalam berbahasa Indonesia juga terpengaruh oleh logat masing-masing etnik. Dalam keluarga sudah tentu memakai bahasa dan identitas suku bangsanya, tetapi sering juga individu-individu yang bisa memakai atribut suku bangsa lain, disebabkan karena terjadi perubahan kiblat kemajemukan suku bangsa tersebut.

Orientasi nilai budaya yang dipunyai masing-masing etnik mengalami pembauran dan percampuran, terlihat pada kebutuhan jasmani dan norma-norma yang ada seperti cara berpakaian, adat istiadat yang longgar, ritus-ritus yang meniru etnik lain, upacara perkawinan dan kematian. Pola perubahan yang terjadi dalam masyarakat Jambak cenderung mengarah pada pola budaya Jawa karena merupakan penduduk yang mayoritas. Roda kebudayaan Minangkabau juga tidak jauh ketinggalan, sedangkan pola budaya Batak hanya terbatas pada lingkungan keluarganya saja karena jumlahnya relatif kecil, baik penampilan dan juga pendukungnya.

Pengaruh dari interaksi penampilan dan juga pendukungnya, mempunyai arti penting terhadap maju mundurnya pembangunan Desa Jambak. Kuatnya interaksi yang diwujudkan masyarakat akan menghasilkan rasa bersatu yang utuh dan stabilitas daerah terjamin dan memudahkan melangsungkan pembangunan dengan adanya konflik merupakan penghambat pembangunan dan pertumbuhan daerah tersebut.

\section{PENUTUP}

Bisa dikatakan, Pasaman Barat merupakan mininya Indonesia. Daerahnya yang unik dengantiga etnis yakni Jawa, Minangkabau dan Mandailing bergumul dan berinteraksi secara baik di daerah tersebut. Di rantau nya Minangkabau tersebut, etnik Minangkabau sebagai penduduk asli (urang asa) menganggap dua etnik yakni Mandailing dan Jawa sebagai penduduk pendatang (urang datang).

Setelah etnis Minangkabau menempati daerah ini, datanglah orang dari Tapanuli Selatan, yang beretnis Mandailing. Awal kedatangan mereka tidak terlepas dari munculnya gerakan Paderi, memasuki abad ke 19 di Minangkabau, sebuah gerakan yang menyerukan "kembali ke syariat Islam" yang berdasarkan Al-Qur'an dan Hadist Nabi Muhammad SAW. Ini merupakan periode pertama, kedatangan mereka ke daerah Pasaman. Periode kedua, tahun 1930-an ketika pemerintah kolonial Belanda membangun sektor perkebunan karet di Pasaman. Seiring dengan pembangunan sektor perkebunan tersebut, maka orang dari Tapanuli Selatan datang ke Pasaman. Periode ketiga, tahun 1950-an. Migrasi tersebut cukup menghebohkan di daerah tersebut. Besarnya jumlah mereka, pernah 
dimuat oleh harian lokal tahun 1953 sekitar 200 kelamin, jumlah tersebut terus bertambah, tahun 1957 tercatat puluhan ribu orang.

Berbeda dengan migrasi orang Minangkabau dan Mandailing, migrasi orang Jawa ke Pasaman, tidak terlepas dari kedatangan pemilik modal ke daerah Pasaman awal tahun 1900-an. Walaupun sebelumnya keberadaan orang Jawa di Sumatera Barat telah ada, yakni dibawa oleh Belanda sebagai kuli kontrak dan kuli paksa untuk bekerja di tambang. Bagi pemerintah kolonial Belanda mendatangkan pemilik modal ke daerah ini tidak terlepas dari daerah tersebut cukup luas dan subur untuk lahan perkebunan. Disamping itu adanya pelabuhan-pelabuhan kecil sebagai sarana penunjang untuk proses distribusi hasil. Pelabuhan tersebut adalah pelabuhan Sasak dan Air Bangis. Kedatangan pemilik modal di Pasaman ditandai dengan munculnya perusahaan perkebunan N.V.Syndicaat Ophir tahun 1911, N.V.Syndicaat Ophir, N.V. Sumatera Thee Mij, N.V.Tapanoeli, N.V.Talamaoe dan satu perusahaan belum punya nama yang dipimpin oleh C.Knegtmans. Untuk tenaga kerja di perkebunan terdiri dari buruh bebas Jawa (vrije Java) dan buruh lepas (losse Arbeiders) yang umumnya adalah suku Melayu. Menurut laporan kamar dagang Belanda di Padang, pada akhir tahun 1935 buruh Jawa yang bekerja di perusahaan N.V.Cultuur Maatschappij Ophir sebanyak 1.710 orang, buruh lepas sebanyak 142 orang. Awal tahun 1936 buruh yang bekerja 1.852 orang. Buruh inilah yang dimanfaatkan oleh perusahaan Belanda untuk mengerjakan pembangunan kelapa sawit Ophir.

Etnis Minangkabau, Mandailing dan Jawa mempunyai pola budaya dan sifat khas yang mengarah pada kebudayaan yang mereka miliki. Bagi penduduk pendatang (urang datang) setibanya mereka ditempat pemukiman yang baru mereka menemukan kehidupan yang baru pula, berbaur antar etnik tersebut, sudah tentu berbeda dengan daerah asal mereka dahulu bahkan semula tidak mengenal antara satu individu, kelompok dan juga etnik yang dipunyai. Masing-masing mereka mengalami perubahan-perubahan karena harus beradapatasi pada lingkungan yang baru, baik cara hidup, cara bergaul dan hubungan sosial lainnya. Dalam rangka hubungan antar individu khususnya dan hubungan antar etnik umumnya maka proses interaksi antar etnik dapat dilihat keberadaannya. Sebab pertemuan latar belakang budaya yang berbeda dalam satu komunitas, hal ini mengandung makna hadirnya corak kehidupan baru yang juga ditandai oleh kebiasaan, pola tingkah laku dan nilai sosial budaya yang berbeda.

Antara ketiga etnis tersebut, telah terjalin interaksi yang terjadi dalam dua bentuk suasana. Pertama, suasana formal yang mempunyai aturan-aturan resmi dalam mengadakan hubungan-hubungan sosial, terjadi wadah organisasi masyarakat seperti organisasi pemuda, Karang Taruna, PKK, kelompok tani dan organisasi lainnya. Kedua, suasana informal dimana interaksi sosial terjadi tidak memakai aturan resmi hanya terjadi secara spontan dalam bentuk hubungan sehari-hari tergantung pada kesempatan dan kebutuhan bagi masyarakat.

Dengan adanya tempat tinggal yang bercampur baur antara etnik yang berlainan di tempat pemukiman tanpa ada pengelompokan berdasarkan etnik mempermudah terjadinya interaksi. Serta mengurangi jarak sosial antara penduduk yang berlainan suku bangsa. 


\section{DAFTAR PUSTAKA}

Abdullah, Taufik, 1996. Sejarah Lokal di Indonesia. Yogyakarta : Gadjah Mada University Press. Abdullah, Irwan, 2006. Konstruksi dan Reproduksi Kebudayaan. Yogyakarta : Pustaka Pelajar. Amran, Rusli, 1985, Sumatera Barat hingga Plakat Panjang. Jakarta : Sinar Harapan.

Aboe Nain, Sjafnir, 1988, Tuanku Imam Bonjol : Sejarah Intelektual Islam di Minangkabau 17841832. Padang : Esa.

Asnan, Gusti, 2003, Kamus Sejarah Minangkabau. Padang: Pusat Pengkajian Islam dan Minangkabau (PPIM).

Asfahrizal,1996, Sejarah Perkebunan Kelapa Sawit Ophir dari Onderneming hingga Perkebunan Inti Rakyat di Pasaman Sumatera Barat. Skripsi . Padang : Fakultas Sastra Universitas Andalas.

Departemen Pendidikan dan Kebudayaan Tim Peneliti Cerita Rakyat Daerah Sumatera Barat, 1979/ 1980. Cerita Rakyat (Mite dan Legende) Daerah Sumatera Barat dalam Bahasa Daerah Minangkabau. Jakarta : Proyek inventarisasi dan dokumentasi kebudayaan daerah pusat penelitian sejarah dan budaya Departemen Pendidikan dan Kebudayaan.

Dobbin, Christine, 1992. Kebangkitan Islam dalam Ekonomi Petani yang Sedang Berubah, Sumatera Tengah, 1784-1847. Jakarta : INIS.

Evert S. Lee, 1976. Suatu Teori Migrasi, Terjemahan. Yogyakarta : Lembaga Kependudukan Universitas Gadjah Mada.

Graves, Elizabeth. 1981. The Minangkabau Response to Dutch Colonial Rule in The Nineteenth Century (Monograph series). Ithaca, New York : Cornell University.

Gottschalk, Louis, 1985. Mengerti Sejarah. Terjemahan oleh Nugroho Notosusanto. Jakarta : Universitas Indonesia Press

Haluan, 18 September 1953

Haluan, 27 Juli 1957.

Haluan, 11 Nopember 1954.

Hardjo, S.M, 1989. Bunga Rampai dari Suriname ke Tongar. Jakarta : Balai Pustaka

Kahin, Audrey, 2005, Dari Pemberontakan ke Integrasi : Sumatera Barat dan Politik Indonesia : 1926-1928. Jakarta : Yayasan Obor Indonesia.

Koentjaraningrat, 1984, Masalah-masalah Pembangunan : Bunga Rampai Antropologi Terapan. Jakarta : LP3ES.

1994. Kebudayaan Jawa. Jakarta : Balai Pustaka.

,1992. "Aneka Warna Manusia dan Kebudayaannya” dalam Koentjaraningrat, Manusia dan Kebudayaan di Indonesia. Jakarta : Djambatan.

1989. Masyarakat Desa di Indonesia. Jakarta : Lembaga Penerbit Fakultas Sastra Universitas Indonesia, 1989.

1979. Pengantar Antropologi Sosial. Jakarta : Aksara Baru.

1984. Masalah-Masalah Pembangunan Nasional dalam Bunga Rampai Antropologi

Terapan. Jakarta : LP3S, Jakarta.

1984. Masyarakat Desa di Indonesia. Jakarta : FE UI.

Koriun, H.B, 1999. Perkampungan Suriname : Studi tentang Repatrian Suriname di Tongar (19541993). Skripsi S1. Padang : Fakultas Sastra Universitas Andalas.

Kuntowijoyo, 1999. Pengantar Ilmu Sejarah. Jakarta : Yayasan Bentang Budaya.

Laporan Umum Jajasan Tanah Air Tahun 1954, Lingkin Baru (Tongar);15 Mei 1955

Majalah Tiras, nomor 32, 5 September 1996

Majalah Warta Caltex nomor.34 tahun 1993

Naim, Muchtar (ed), 1968.Menggali Hukum Tanah dan Hukum Waris Minangkabau. Padang : Center For Minangkabau Studies.

1974.Merantau : Minangkabau Voluntary Migration, Disertasi Ph.d, Singapore : Faculty of Arts and Social Sciences University of Singapore.

1977. Kedudukan Tanah Adat Dewasa Ini. Kertas kerja yang disampaikan pada simposium "Undang-undang Pokok Agraria dan Kedudukan Tanah Adat Dewasa ini”. Diselengarakan oleh 
Badan Pembinaan Hukum Nasional,Departemen Kehakiman bekerjasama dengan Pemerintah Daerah Kalimantan Selatan dan Fakultas Hukum Universitas Lambung Mangkurat tanggal 6 sampai dengan 8 Oktober 1977 di Banjarmasin.

Nagazumi, Akira (Penyunting), 1986, Indonesia dalam Kajian Sarjana Jepang : Perubahan SosialEkonomi Abad XIX dan XX dan Berbagai Aspek Nasionalisme Indonesia. Jakarta : Yayasan Obor Indonesia.

Oki, Akira, 1977. "Social Change in The West Sumatran Village. 1908-1945" Thesis Doctor. Canberra : The Australian University.

O etoesan M inangkabau: Sasaran Penghoeloe Medan Ra'jat tanggall 27 Maart 1939. Nomor 1 Tahoen ke 5

Oetoesan Minangkabau: Sasaran Penghoeloe Medan Ra'jat. Tahoen 5. nomor 1. 27 Maart 1939 Oetoesan Alam Minangkabau Tahun I Nomor 5 Maart 1939

Parlindungan, Mangaradja Onggang, 1964, Pongkinangolangolan Sinambela gelar Tuanku Rao :

Teror agama Islam mazhab hambali di Tanah Batak 1816-183 Djakarta : Tandjung Pengharapan.

Suparlan Parsudi, 1982. "Jaringan Sosial” dalam Media IKA, Nomor 8 Tahun X. Februari. Jakarta.

Soeara Minangkabaoe Tahoen 1 nomor 1 Augustus 1938

Pelly, Usman, 1984, Urbanisasi dan Adaptasi : Peranan Misi Budaya Minangkabau dan Mandailing. Jakarta : LP3ES.

Sahur, Ahmad dkk, 1988. Migrasi, Kolonisasi Perubahan Sosial. Jakarta : Pustaka Grafika Kita.

Surat Penjerahan Tanah dari Walinagari Kepada Pemerintah Republik Indonesia. Tertanggal 18 Mei 1953. Surat tersebut berisi tentang penyerahan tanah oleh walinagari di Pasaman Barat kepeda pemerintah daerah untuk transmigrasi,

Surat Keterangan Bupati/Kepala Daerah Kabupaten Pasaman, Lubuk Sikaping. Tertanggal 25 April 1953. Surat tentang tidak keberatannya pemerintah daerah Kabupaten Pasaman atas kedatangan para transmigrasi Jawa ke daerahnya.

Tirtosudarmo, Riwanto, 2005. "Demografi Politik Kalimantan Barat Sebagai Daerah Perbatasan" dalam Riwanto Tirtosudarmo dan John Haba (Penyunting), Dari Entikong sampai Nunukan : Dinamika Daerah Perbatasan Kalimantan Malaysia Timur (Serawak-Sabah).Jakarta : Sinar Harapan. Undri, 2004, "Heboh di Daerah Perbatasan 1930-1960 : Studi Kasus Konflik Lahan Perkebunan Karet Rakyat di Kecamatan Rao Mapat Tunggul Kabupaten Pasaman Propinsi Sumatera Barat". Laporan Penelitian. Padang, Sumatera Barat.

, 2005, Halului Anak Halului Tano. Menelusuri Konflik Pengusahan Lahan Perkebunan Karet Rakyat di Kabupaten Pasaman Propinsi Sumatera Barat. Makalah yang disampaikan di Lembaga Ilmu Pengetahuan Indonesia (LIPI). Jakarta, 10 Januari 2005. 2006, Konflik Tanah di Dearah Perbatasan (Studi Kasus Tiga Kelompok Etnik di Pasaman,

Sumatera Barat 1930-1960) dalam http://www.geocities.ws/konferensinasionalsejarah/undri_siun. 2009. Migrasi, Perebutan Akses Tanah dan Penguatan Lembaga Adat : Resolusi Konflik

Tanah di Rantau Minangkabau. Jurnal Masyarakat dan Budaya. Volume 11 Nomor 2 Tahun 2009. Jakarta : Lembaga Ilmu Pengetahuan Indonesia Pusat Penelitian Kemasyarakatan dan Kebudayaan (PMB-LIPI).

2009. Orang Pasaman : Menelusuri Sejarah Masyarakat di Rantau Minangkabau. Padang : Lembaga Kajian Gerakan Paderi (Center for Studies of the Padri Movement), Gebu Minang, Pemerintah Kabupaten Pasaman, dan Balai Pelestarian Sejarah dan Nilai Tradisional Padang.

2009, Orang Jawa di Rantau Minangkabau, Jurnal Jantra : Jurnal Sejarah dan Budaya. Volume IV nomor 7 Juni 2009 ISSN 1907-9605. Diterbitkan oleh Departemen Kebudayaan dan Pariwisata Balai Pelestarian Sejarah dan Nilai Tradisional Yogyakarta.

Uripsyah, Yadri, 1990. Integrasi dan Konflik Etnik di Pemukiman Baru : Studi Kasus Desa Jmabak Kabupaten Pasaman.Skripsi S1. Padang : Fakultas Sastra Universitas Andalas. 
Utomo, Muhajir dan Rofiq Ahmad (ed), 1997. 90 Tahun Kolonisasi 45 Tahun Transmigrasi. Jakarta : Puspa Swara.

Yenti, Basu. 2000. Kehidupan Transmigrasi Nagari Desa Baru Kecamatan Sungai Beremas Kabupaten Pasaman 1953-1997. Skripsi S1. Padang : Fakultas Sastra Universitas Andalas.

Westenenk.L.C.[1978] Nagari Minangkabau. Terjemahan oleh Mahyuddin Saleh. Padang : Bursa Fakultas Hukum Universitas Andalas.

Zed, Mestika, 1993, Melayu Kopi Daun : Eksploitasi Kolonial dalam Sistem Tanaman Paksa Kopi di Minangkabau Sumatera Barat (1847-1908)”. Thesis. Jakarta : Pascasarjana Bidang Studi Ilmu Sejarah Indonesia Pengkhususan Sejarah Indonesia Universitas Indonesia. 